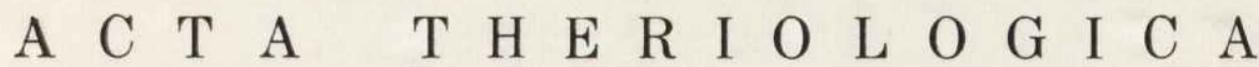

VOL. XVII, 13: 151-169. BIAŁOWIEŻA $\quad$ August, 1972

BISONIANA LI

\author{
Stanisław B ORO W S K I \& Simona K O S A K
}

\section{The Natural Food Preferences of the European Bison in Seasons Free of Snow Cover}

[With 9 Tables \& 4 Figs.]

\begin{abstract}
Field studies in 6 forest associations carried out by the direct observation method and study area method made it possible to define the European bison's food preferences. These animals feed on 137 species of plants, which number includes 27 species of trees and shrubs, 14 species of grasses and sedge, and 96 species of dicotyledonous forbs. Marked preference is shown for the following trees and shrubs Carpinus betulus, Salix caprea, Fraxinus excelsior and Betula pubescens; Grasses and sedges - Calamagrostis arundinacae, Carex silvatica and Carex hirta; Dicotyledonous forbs - Aegopodium podagraria, Urtica dioica, Ranunculus lanuginosus and Cirsium oleraceum. The following trees are most often stripped of bark: Quercus robur, Carpinus betulus, Fraxinus excelsior and Picea excelsa. Three group of plants eaten by European bison were distinguished i.e. those (1) eaten proportionally to their abundance, (2) especially preferred, but with low abundance, and (3) occuring abundantly but forming a negligible percentage of the European bison's food. The preferences for species exhibited by those animals was traced in relation to type and age of biotype. It was found that European bison most frequently feed on plantations and in Calamagrostio-Quercetum and Tilio-Carpinetum forest associations. The percentage formed by the different groups of plants in the European bison's food was defined as follows: trees and shrubs $33 \%$, grasses and sedges and herb plants $67 \%$.
\end{abstract}

\section{INTRODUCTION}

The number of free-living European bison in the Białowieża Primeval Forest at the end of 1969 was $180,1970-197,1971-211$. Although the animals have wandered into all parts of the Forest, $80 \%$ of the herd is concentrated in an area of approx. 17,680 ha ( $\mathrm{Kr}$ a siński, 
1967). In view of the very large number of these animals it has become a matter of importance to determine the food resources of the habitat and also the qualitative and quantitative composition of the food of the European bison (P u cek, 1967). We have already obtained a certain amount of data on species of plants included in the European bison's food, from different sites in the contemporaneously reconstructed range of this species. Among more recent studies the detailed investigations made by Krajnova (1951), Kamienska ja (1956), Koročkina (1966, 1969 a, b, 1971) and Čičikina \& Čičikin (1967), deserve mention. Preliminary list of plant species forming the European bison's food in the Polish part of the Białowieża Primeval Forest is given in the study by Borowski, Krasiński \& Miłkowski (1967).

The majority of the authors have limited themselves to giving a list of species and possibly dividing plants into those more or less readily eaten by European bison. The present study was made on account of the need for dealing with this question from the quantitative aspect. The aim of this paper was to investigate the European bison's preferences for its natural food depending on the latter's abundance, and the type and age of the given forest, and also to establish the percentage of trees and shrubs, grasses and herbs contained in their food, as this is of great importance to forest management.

\section{MATERIAL AND METHODS}

Studies on the food preferences of free-living European bison in the Białowieża Primeval Forest were carried out during the period from 1966-1971. During the first two years (1966/67 and 1967/68) attention was concentrated on the composition of these animals' food, in order to draw up an approximate list of the plant species they eat. The method used consisted in direct observation and following the feeding animals. During this time the senior author followed up the routes taken by different herds of European bison, which taken jointly amounted to $47 \mathrm{~km}$ (247 hours of observations). In 1968/69, 1969/70 and 1970/71 particular attention was given to the quantitative composition of the animals' food, and for this purpose 60 study areas were chosen, measuring $10 \times 50 \mathrm{~m}$, in places frequented by European bison, in 6 forest associations: Peucedano-Pinetum Mat. $1962(P-P)$, Pino-Quercetum Kozl. 1925 (P-Q), Calamagrostio-Quercetum (Hartm. 1934) Scam. 1959 (C-Q), Tilio-Carpinetum Tracz. 1962, high Mazurian variant $\left(T-C_{1}\right)$, Tilio-Carpinetum Tracz. 1962, low Mazurian variant (T-C $\left.C_{2}\right)$, Circaeo-Alnetum Oberd. $1953(C-A)^{1}$. The study plots were distributed in main area of concentration of bison's herds, in three forest administration districts: Zwierzyniec - 51, Hajnówka -4 , Narewka -5 . In each of the associations studied 5 areas were located in young tree plantations and thickets, 4 in pole-sized stands, and 1 in timber stands.

1 Terminology after Matuszkiewicz (1967). 
Detailed botanical documentation was made of the study areas, together with floristic lists, in early spring and late autumn. From mid-November up to the end of April the European bison congregate near sites where food is put out for them (Krasiński, 1967), which causes almost total cessation of these animals' wanderings over areas at a distance from the feeding places, and consequently the effective observation period lasted $61 / 2$ months each year.

The study plots were inspected twice montly (S. B. with two technical assistants). As from December 1968 to November 1971 a total of 4320 inspections were made, during the course of which feeding European bison were observed on a total of 48 areas. The number of contacts (bites) between European bison and plants were counted and marked. By contact is meant cropping 1 clump of grass or sedge, eating 1 shoot or ripping off leaves from one shoot of tree or shrub, $1 \mathrm{dcm}^{2}$ of grass or sedge grazed on the ground and consumption (wholly or partly) of 1 individual herb plant. Barking was counted in $\mathrm{cm}^{3}$ of bark stripped from the trunk.

Since contacts recorded in this way might differ from each other as to mass, an attempt was made at rendering data uniform. For this purpose samples corresponding to contacts were taken in areas near the

Table 1

Samples taken to obtain conversion values in the tree, shrub and dwarf-shrub group (browsing).

Species
No. of samples each of 100 bites
Dry mass, Dry mass of 1 bite g
Conversion value

\begin{abstract}
Betula verrucosa
Carpinus betulus

Fraxinus excelsior

Salix caprea

Tilia cordata
\end{abstract}

$\left.\begin{array}{rrr|r}4 & 103.5 & 0.26 \\ 4 & 66.3 & 0.16 \\ 3 & 92.3 & 0.31 \\ 5 & 152.7 & 0.30 \\ 3 & 63.1 & 0.21\end{array}\right\} 0.25$

study areas from species of trees and shrubs, grasses and sedges and herbs most frequently eaten by European bison, and then conversion values between them were defined on the basis of the dry mass of different groups of plants.

For this reason samples were taken from the tree and shrub group:

(a) Nineteen samples of 100 contacts each (shoots with leaves) from the 5 species most frequently eaten by European bison (Carpinus betulus, Salix caprea, Fraxinus excelsior, Tilia cordata, Betula verrucosa). After measuring volume the samples were weighed and dried in an oven, at $80^{\circ} \mathrm{C}$ until dry mass was obtained. Calculation was made of the weight of one shoot browsed (Table 1).

(b) Ninety one samples were taken of different sized pieces of bark from 6 species of trees from which bark was most often stripped (Quercus 
robur, Carpinus betulus, Fraxinus excelsior, Alnus glutinosa, Picea excelsa). The diameter of the trees varied from 5 to $25 \mathrm{~cm}$, since trees with lesser or greater diameter are rarely stripped. The volume of each sample was measured in two ways: (1) that used under field conditions, consisting in measuring average length, width and thickness with a millimeter scale measure, and (2) that used in the laboratory, consisting in measuring the volume of bark with a measuring glass. The results obtained by these two methods differed from each other (Table 2). Field

Table 2

Definition of error made in assessing mass of stripped bark in field.

\begin{tabular}{lcccr}
\hline \multicolumn{1}{c}{ Species } & $\begin{array}{c}\text { No. of } \\
\text { samples }\end{array}$ & $\begin{array}{c}\text { Size of sample } \\
\text { field }\end{array}$ & $\begin{array}{c}\left(\mathrm{cm}^{3}\right) \text { measured in: } \\
\text { laboratory }\end{array}$ & $\begin{array}{r}\text { Percent of } \\
\text { error }\end{array}$ \\
\hline Alnus glutinosa & 10 & 192.3 & 182.0 & 5.7 \\
Carpinus betulus & 10 & 72.9 & 62.5 & 16.7 \\
Fraxinus excelsior & 10 & 146.6 & 131.0 & 11.9 \\
Picea excelsa & 21 & 509.9 & 454.0 & 12.3 \\
Quercus robur & 10 & 271.6 & 245.0 & 12.8 \\
Salix caprea & 10 & 188.1 & 158.0 & 10.9 \\
\hline
\end{tabular}

Table 3

Estimate of conversion value for $1 \mathrm{~cm}^{3}$ stripped bark.

\begin{tabular}{|c|c|c|c|c|}
\hline Species & $\begin{array}{c}\text { Dry mass of all } \\
\text { samples }\end{array}$ & $\begin{array}{l}\text { Dry mass } \\
\text { of } 1 \mathrm{~cm}^{3}, \mathrm{~g}\end{array}$ & \multicolumn{2}{|c|}{ Conversion value } \\
\hline Alnus glutinosa & 92.1 & 0.50 & $5.9)$ & \\
\hline Carpinus betulus & 31.8 & 0.50 & 5.9 & \\
\hline Fraxinus excelsior & 68.7 & 0.52 & 6.2 & $6.0 *$ \\
\hline Picea excelsa & 167.7 & 0.37 & 4.3 & $0.0^{*}$ \\
\hline Quercus robur & 118.0 & 0.48 & 5.7 & \\
\hline Salix caprea & 84.1 & 0.53 & $6.3)$ & \\
\hline
\end{tabular}

* Without Picea excelsa.

measurements were over-estimated by 11 to $19 \%$ (Alnus glutinosa exceptionally by $5.7 \%$ ). This error was corrected in later elaborations of the material. The samples were dried until constant mass was obtained. The weight of $1 \mathrm{~cm}^{3}$ of dry mass of bark was calculated, and found to be $0.5 \mathrm{~g}$. An exception was Picea excelsa, the bark of which is lighter (approx. 0.4/1 $\mathrm{cm}^{3}$ ) (Table 3). This has been taken into consideration in elaboration.

Samples taken from the grass and sedge group:

(a) Five samples of grasses and sedge with an admixture of small dicotyledonous forbs. The various samples were cut just above the ground 
from an area of $1 \mathrm{~m}^{2}$, and weight of $1 \mathrm{dcm}^{2}$. calculated from their dry mass. This figure was $0.95 \mathrm{~g}$ (Table 4).

(b) Five samples of 100 clumps of Carex digitata (on account of the small dimensions of this sedge) and two samples of 100 clumps of

Table 4

Estimate of conversion values in grass and sedge group.

\begin{tabular}{|c|c|c|c|c|c|}
\hline Item & $\begin{array}{c}\text { No of } \\
\text { samples }\end{array}$ & $\begin{array}{l}\text { Dry mass } \\
\text { in } \mathrm{g} .\end{array}$ & $\begin{array}{l}\text { Mass of } \\
\text { one unit } \\
(\text { clump or } \\
\left.\text { dcm }^{2}\right)\end{array}$ & $\begin{array}{l}\text { Avg. } \\
\text { mass }\end{array}$ & $\begin{array}{c}\text { Con- } \\
\text { version } \\
\text { value }\end{array}$ \\
\hline \multirow{4}{*}{$\begin{array}{l}\text { Area-species samples } 1 \mathrm{~m}^{2} \\
\text { (Grasses, sedges and small } \\
\text { dicotyledonous forbs) } \\
\text { Carex digitata, clumps } \\
\text { Calamagrostis arundinacea, } \\
\text { clumps }\end{array}$} & & & & \multirow{4}{*}{$\begin{array}{c}- \\
0.69\end{array}$} & \multirow{4}{*}{$\begin{array}{r}11.2 \\
8.1\end{array}$} \\
\hline & 5 & 474.86 & 0.95 & & \\
\hline & 500 & 218.55 & 0.44 & & \\
\hline & 200 & 187.60 & 0.94 & & \\
\hline
\end{tabular}

Table 5

Conversion values in dicotyledonous forbs.

$\begin{array}{ccccc}\text { Group \& species } & \begin{array}{c}\text { No. of samples } \\ \text { each of } \\ 100 \text { bites }\end{array} & \begin{array}{c}\text { Dry mass } \\ \mathrm{g}\end{array} & \text { Dry mass of } 1 \text { bite } & \begin{array}{c}\text { Conversion } \\ \text { value }\end{array}\end{array}$

\begin{tabular}{|c|c|c|c|c|c|c|}
\hline & $\begin{array}{l}\text { Ajuga reptans } \\
\text { Galeobdolon luteum } \\
\text { Veronica chamaedrys }\end{array}$ & $\begin{array}{l}4 \\
4 \\
4\end{array}$ & $\begin{array}{l}33.09 \\
34.24 \\
34.77\end{array}$ & $\begin{array}{l}0.08 \\
0.08 \\
0.09\end{array}$ & 0.08 & 1.0 \\
\hline B. & $\begin{array}{l}\text { Impatiens noli-tangere } \\
\text { Ranunculus lanuginosus } \\
\text { Ranunculus repens }\end{array}$ & $\begin{array}{l}4 \\
4 \\
4\end{array}$ & $\begin{array}{l}54.30 \\
36.69 \\
67.01\end{array}$ & $\begin{array}{l}0.13 \\
0.09 \\
0.17\end{array}$ & 0.13 & 1.5 \\
\hline C. & $\begin{array}{l}\text { Cytisus nigricans } \\
\text { Genista tinctoria }\end{array}$ & $\begin{array}{l}2 \\
1\end{array}$ & $\begin{array}{l}27.08 \\
12.75\end{array}$ & $\begin{array}{l}0.13 \\
0.13\end{array}$ & 0.13 & 1.5 \\
\hline D. & $\begin{array}{l}\text { Filipendula ulmaria } \\
\text { Solidago virga-aurea } \\
\text { Stachys silvatica } \\
\text { Urtica dioica }\end{array}$ & $\begin{array}{l}2 \\
2 \\
4 \\
4\end{array}$ & $\begin{array}{r}107.85 \\
21.08 \\
138.30 \\
159.68\end{array}$ & $\begin{array}{l}0.54 \\
0.10 \\
0.34 \\
0.40\end{array}$ & 0.34 & 4.1 \\
\hline E. & $\begin{array}{l}\text { Aegopodium podagraria } \\
\text { Anemone nemorosa } \\
\text { Caltha palustris } \\
\text { Chaerophyllum hirsutum } \\
\text { Cirsium arvense } \\
\text { Cirsium oleraceum }\end{array}$ & $\begin{array}{l}4 \\
1 \\
2 \\
1 \\
1 \\
1\end{array}$ & $\begin{array}{r}91.35 \\
14.48 \\
34.80 \\
31.12 \\
30.67 \\
101.26\end{array}$ & $\begin{array}{l}0.23 \\
0.14 \\
0.17 \\
0.31 \\
0.31 \\
1.01\end{array}$ & 0.36 & 4.3 \\
\hline
\end{tabular}

Calamagrostis arundinacea. After obtaining constant dry mass the average weight of 1 clump was calculated, and found to be $0.7 \mathrm{~g}$ (Table 4). 
In the group of dicotyledonous forbs 49 samples were taken of 18 species of plants, and these species divided into classes according to size of plants (Table 5). Average mass of 1 contact was calculated for each of these classes, and found to be from 0.08 to $0.54 \mathrm{~g}$.

Taking as a unit mass of one bite of plants from the herb group $A$, on account of their greatest percentage in the European bison's food (about $40 \%$ ), conversion values - equivalents were calculated for the other groups dicotyledonous forbs, grasses, sedges, trees and shrubs. In all further discussion the concept of contact (bite) must be taken to mean unified convertible units obtained from multiplying field data by conversion values defined in above way.

In winter the presence of European bison in the study areas was established mainly on the basis of tracks, in summer by means of tracks, excreta, shed hair and traces of feeding. As deer were often present in the areas only those observations in which the food consumed could be attributed with complete certainty to European bison were taken into account (233 observations - 645 cases of European bison being present in the study areas). This resulted in reduction of the joint amount of material (which also affected the number of species contained in the list of plants forming the European bison's food), but made it possible to avoid errors due to incorrect interpretation of results.

The abundance of occurrence of the various species in the areas was calculated from phytosociological records made by the Braun-Blanquet method ( $\mathrm{Paw}$ lowsk i, 1959).

\section{RESULTS}

\section{Species Preferences}

The whole of the results obtained in study areas during the 3-year study period have been set out in species lists of trees, shrubs and dwarf-shrubs, grasses and sedges, and dicotyledonous forbs eaten by European bison in 6 types of forest (Table 6). These data were arranged in groups according to the percentage of the different species in the European bison's food. Each group ended with species which did not occur on the study areas but, as shown by observations previous to the time the areas were set up, are included in the food of these animals in the Białowieża Primeval Forest.

Material collected from the areas consisted of a total number of 480,285 contacts. In all 112 species of plants on the study plots and including those eaten outside the plots -137 species, were found to be included in the European bison's food.

In the first group including trees, shrubs and dwarf-shrubs 158,615 contacts were recorded, of which 30,826 contacts related to feeding on shoots and leaves, and 127,789 contacts - bark stripping $\left(21,488 \mathrm{~cm}^{3}\right)$. 


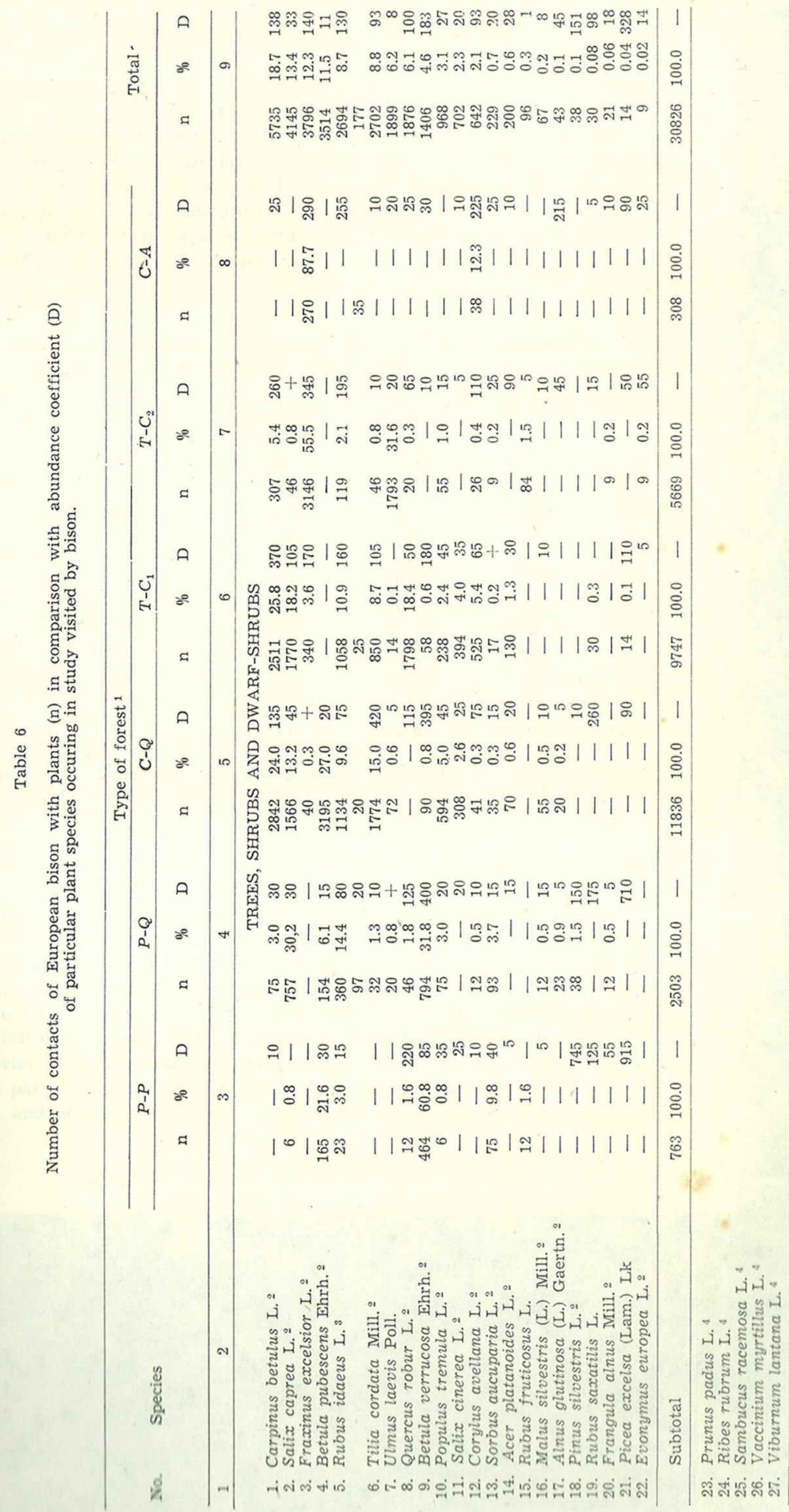




\section{DICOTYLEDONOUS FORBS}

1. Aegopodium podagraria L.

2. Urtica dioica I. ${ }^{3}$

3. Ranunculus lanuginosus $\mathrm{L}$.

- Cirsium oleraceears Scop:

- Contiverer jaceas th

- Impocienar maili-arngene $L_{2}=$

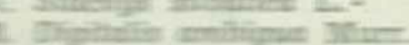

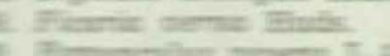

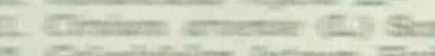

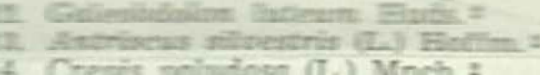

4. Crepis poludose (L.) Mnch. $=$

E. Trants juporsion (Houtt.) D.C.

L Fipendalt slmaria (L.) Maxim. 2

E. Pienumcallas acer L.

A Terunics chamaedrys L.2

( Cencitie tinctoria L.

- Cnmpansila persicifolia L. 2

- Primalia officinalis (L.) Mill.

Dathyras vernus (L.) Berhnh.

Trallifus europaeus L.

Origanum vulgare I.

Ajuga reptans L.

Iapsoma communis $\mathrm{L}$.

- Ftellicx acetosella L.

2. Sanicula europaea L.

2. Calamintha vulgaris (L.) Druce?

3. Solanum dulcamara I

4. Semecio vernalis W.K.

35. Iris pseudoacorus L.

7. Viola silvestris $\mathrm{Rchb}$

38. Lycopus europaeus L.

9. Pulmonaria obscura Dumm. 2

41. Chamaenerion angustifolium (L.)

Scop

2. Mercurrialis perrenis $L$.

43. Lysymachia vulgaris L.

5. Thalictrum flavum L.

56. Picris hieracioides $\mathrm{L}$.

57. Chrysosplenium alternifolium $\mathrm{L}$.

48. Mycelis muralis (L.) Dumm.

9. Galeopsis tetrahit L.

50. Hypericum perforatum L.

51. Antemone nemorosa L.

2. Hepatica nobitis Garsault

54. Hypericum maculatum $\mathrm{Cr}$.

5. Solidago virga aurea L. 2

6. Majanthemum bifolium (L.)

F. W. Schm.

57. Geum urbanum I.

58. Arctium lappa L. I.

6. Caltha palustris $\mathrm{L}$.

61. Aquilegia vulgaris I.

2. Cordamine amara L.

if Dentaria bulbifera I.

5. Hieracium umbellatum I.

E. Stelleria holostea L.

Iscoprem thalictroides I.

Wricie silloatica L:

Wicie segiam L.

Cprrponis trochelinum $\mathrm{L}$.

(Pyperartar apicotam I.

Gonitarm motipo I.

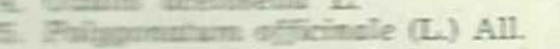

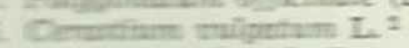

$\begin{array}{lllll}4.5 & 190 & 116 & 1.3 & 45 \\ 1.5 & 35 & 456 & 5.2 & 55\end{array}$

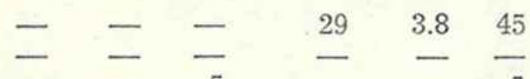

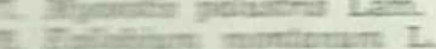

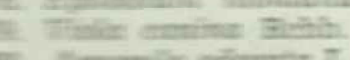

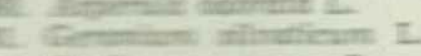

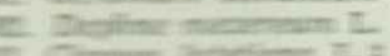

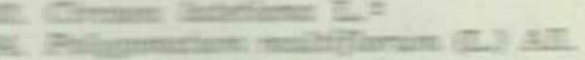

- $=\frac{5}{10}$

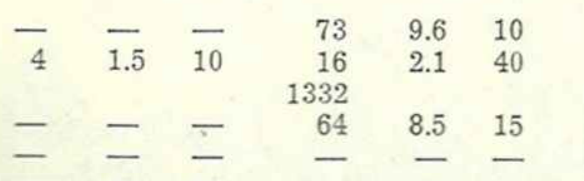

357
2243
1812

$\begin{array}{rr}3.9 & 110 \\ 24.6 & 110\end{array}$

$\begin{array}{rrr}3723 & 42.1 & 290 \\ 520 & 5.9 & 535\end{array}$

$\begin{array}{rrr}561 & 6.1 & 100 \\ 33 & 0.4 & + \\ 1570 & 17.2 & 15\end{array}$

$1146 \quad 13.0 \quad 150$

$\begin{array}{rrr}4 & - & - \\ 1308 & 14.3 & \end{array}$

$\begin{array}{rrr}-\overline{286} & \overline{3.2} & - \\ 1435 & 16.2 & 130\end{array}$

257

$\begin{array}{lr}-2.9 & 35\end{array}$

$\begin{array}{rrrrr}1.5 & 35 & 456 & 5.2 & 69 \\ 09 & 30 & 309 & 43 & 381 \\ 45 & 9 & 9 & \text { in }\end{array}$

$\frac{21}{3.8}$

$\begin{array}{ll}3.8 & \mathrm{~T} \\ 3.8 & 35 \\ 0.3 & 5\end{array}$

$\begin{array}{lr}0.3 & 5 \\ 1.9 & 80\end{array}$

$\begin{array}{rrrrr}1.9 & 80 & \overline{2} & \overline{0} & 10 \\ 0.7 & 140 & 21 & 0.2 & 135 \\ 0.2 & 20 & - & - & -\end{array}$

$\begin{array}{rr}1.3 & 5 \\ -\quad 45\end{array}$

$\overline{0.4}-45$

$\begin{array}{ll}0.4 & -45 \\ 1.3 & 20\end{array}$

$\begin{array}{ll}1.2 & + \\ 0.8 & 45\end{array}$

$\begin{array}{rr}0.8 & 45 \\ 0.4 & 5\end{array}$

- 5

$\overline{0.4} \quad 40$

-

$0.5+$

$\begin{array}{ll}0.5 & 10 \\ 0.3 & 85\end{array}$

$\begin{array}{rrrrrr}\overline{24} & \overline{0.3} & \overline{40} & \overline{16} & \overline{0.1} & \overline{15} \\ 39 & 0.4 & 5 & - & - & -\end{array}$

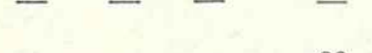

$\begin{array}{rrr}641 & 9.6 & 170 \\ 734 & 10.9 & 1180\end{array}$

\begin{tabular}{rrr}
775 & 11.6 & 50 \\
1500 & 22.4 & 160 \\
\hline
\end{tabular}

$\begin{array}{lll}1064 & 15.9 & 860\end{array}$

$\frac{12}{1030} \quad \frac{0.2}{15.4} \quad \frac{80}{10}$

$\begin{array}{lll}66 & 1.0 & 190\end{array}$

$\overline{35} \quad \overline{0.5} \quad 1^{5}$

$\overline{215} \quad \overline{32} \overline{55}$

$\begin{array}{lll}287 & \overline{4} & \overline{60}\end{array}$

- $\quad$ -

- $\quad$ -

$\frac{2}{72} \quad-5$

- - -

$\begin{array}{rrr}4 & - & 25 \\ 36 & 0.4 & 40\end{array}$

$\begin{array}{llr}13 & 0.1 & + \\ 34 & 0.4 & 5\end{array}$

$\begin{array}{lll}1 & - & 35 \\ 45 & 0.5 & 10\end{array}$

二 $=$

- $\quad \overline{20}$

$\begin{array}{lll}29 & 0.3 & 25\end{array}$$$
\text { - } 5
$$

=

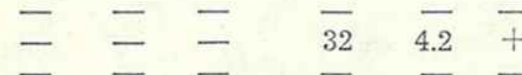

$\overline{\bar{Z}}=\overline{4} \overline{0.5} \overline{15}$

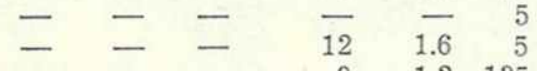

\begin{tabular}{lr}
1.2 & 135 \\
\hline
\end{tabular}

\begin{tabular}{l}
$\overline{7}$ \\
$\overline{2.1}$ \\
\hline 70
\end{tabular}

一 $=\overline{75} \quad \overline{16} \quad 2.1 \quad 70$

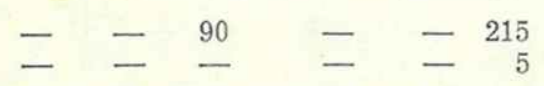

二 $=\overline{10}$ 二 $\overline{\text { 口 }}$

二 $=$ 二 $=\overline{45}$

二 $= \pm$ 二 $=5$

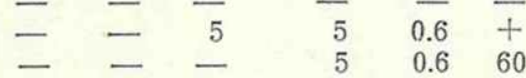

$\overline{0.1} \mp$

$\begin{array}{lr}0.1 & 25 \\ - & 5\end{array}$

- $\quad-\overline{400}$

xs nome

161 100.0

$\begin{array}{rrr}162 & 10.6 & 90 \\ 123 & 8.0 & 1745\end{array}$

1767

\begin{tabular}{lrr}
-52 & 16.3 & 45 \\
\hline & 100
\end{tabular}

$\begin{array}{lll}\overline{180} & \overline{11.7} & 17 \overline{10}\end{array}$

$=\overline{2}$

$\begin{array}{ccc}663 & 43.0 & 340\end{array}$

$\begin{array}{lll}9 & 0.6 & 5 \\ 3 & 2.5 & 60\end{array}$

$= \pm \overline{10}$

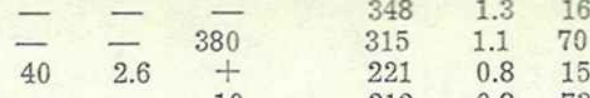

\begin{tabular}{lllll} 
& $-\quad 10$ & 212 & 0.8 & 15 \\
\hline & 5 & 184 & 0.8
\end{tabular}

$= \pm \overline{5}$

$\begin{array}{lll}152 & 0.7 & 17\end{array}$

$\begin{array}{lll}150 & 0.5 & 14\end{array}$

$\begin{array}{lll}145 & 0.5 & 23\end{array}$

$\begin{array}{lll}110 & 0.4 & + \\ 102 & 0.4 & -22\end{array}$

$\begin{array}{lll}90 & 0.3 & 28 \\ 9 & 0.3 & +\end{array}$

8110.3

$\begin{array}{lll}78 & 0.3 & 53\end{array}$

$\begin{array}{lll}59 & 0.2 & 7\end{array}$

$51-0.2-48$

49

49
48

45
40

39

E.

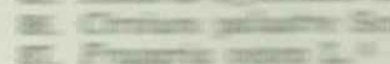

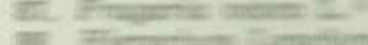

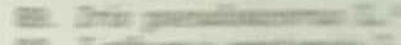

In.

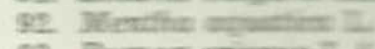

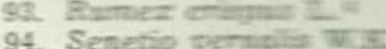

95. Trifolium prefenase IL

96. Serratale tinctorie I.

TOTAL

wax

exis:

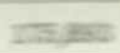

tuses:

토 sen:

$13=$

Jate ebe

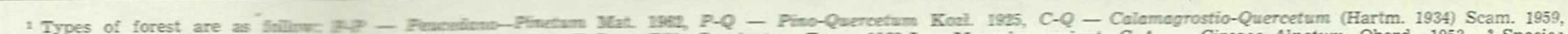

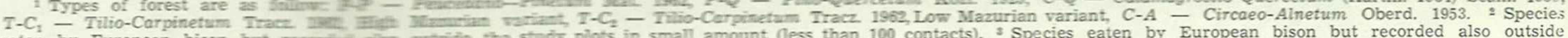

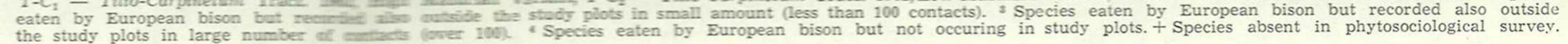


The animals eat 14 species of trees and 8 species of shrubs, with Carpinus betulus - 18.7\%, and Fraxinus excelsior - 12.3\% occupying first places among tree species. Of shrubs Salix caprea - 13.4\% and Rubus idaeus $8.7 \%$ were most frequently browsed. Eight species of trees and 2 species of shrubs were found to have bark bitten and stripped off. The greatest percentage of the total amount of bark stripped was found for Quercus robur - 46.5\%, then Carpinus betulus - 21.5\% and Fraxinus excelsior - $17.0 \%$. The other 7 species form $14.9 \%$ (Table 7 ). A significant

Table 7

Percentage of different species of trees and shrubs in European bison's food obtained by barking.

\begin{tabular}{|c|c|c|c|c|}
\hline \multirow{2}{*}{ Species } & \multirow{2}{*}{$\begin{array}{l}\text { No of } \mathrm{cm}^{3} \text { of } \\
\text { bark recorded } \\
\text { in field }\end{array}$} & \multirow{2}{*}{$\begin{array}{l}\text { Corrected number } \\
\text { of } \mathrm{cm}^{3} \text { of bark }\end{array}$} & \multicolumn{2}{|c|}{ Number of contacts } \\
\hline & & & $\mathrm{n}^{2}$ & $\%$ \\
\hline 1. Quercus robur & 11,347 & 9,895 & 59,370 & 46.5 \\
\hline 2. Carpinus betulus & 5,274 & 4,599 & 27,594 & 21.6 \\
\hline 3. Fraxinus excelsior & 4,158 & 3,626 & 21,756 & 17.0 \\
\hline Fraxinus excelsior ${ }^{3}$ & 396 & 346 & 2,076 & \\
\hline 4. Ulmus laevis & 1,039 & 906 & 5,436 & 4.2 \\
\hline 5. Salix caprea & 791 & 690 & 4,140 & 3.2 \\
\hline 6. Tilia cordata & 774 & 675 & 4,050 & 3.2 \\
\hline Tilia cordata ${ }^{3}$ & 116 & 101 & 606 & \\
\hline 7. Picea excelsa & 702 & 612 & 2,631 & 2.0 \\
\hline Picea excelsa ${ }^{3}$ & 9,037 & 7,880 & 33,884 & \\
\hline 8. Alnus glutinosa & 471 & 411 & 2,466 & 1.9 \\
\hline 9. Acer platanoides & 56 & 49 & 196 & 0.2 \\
\hline Acer platanoides ${ }^{3}$ & 120 & 105 & 630 & \\
\hline 10. Corylus avellana & 29 & 25 & 150 & 0.2 \\
\hline Total & 24,641 & 21,488 & 127,789 & 100.0 \\
\hline
\end{tabular}

1 Taking into consideration the average error calculated in Table 2. 2 Obtained by multiplying corrected data by average conversion value (cf. Table 3 ). ${ }^{3}$ Data obtained during years proceding setting up of study plots.

difference is observed in the European bison's feeding activities on the given species of plant depending on the way in which the food is obtained (Table 8). For instance Quercus robur, which comes first in order of amount of barking, formed only $6.1 \%$ of the food obtained by browsing. and conversely Salix caprea - forms only $3.2 \%$ of food obtained by barking, and $13.4 \%$ of shoot food. There is also a significant difference in the way these animals obtain tree food depending on the plant's age. The European bison strips bark mainly from trees from 4 to $15 \mathrm{~cm}$ in diameter, although traces of barking are found on older treés, usually from parts of roots above grounds. It is chiefly one-year old shoots of trees and shrubs of different ages which are browsed. The foregoing 
shows that damage done by European bison chiefly affects plantations and thickets (barking combined with browsing).

In the second group containing grasses and sedges a total of 294,451 contacts was recorded, out of which it was possible to distinguish only 971 contacts with plants identified to 6 species (Calamagrostis arundinacea, Carex silvatica, Carex hirta, Milium effusum, Melica nutans, Deschampsia caespitosa). This was due to complete consumption of small plants by European bison, making identification of different species impossible. Food consumed in this way was calculated per $\mathrm{m}^{2}$ and allocated to the grass and sedge group, which does not rule out the possibility that there might have been an admixture in it of small dicotyledonous forbs. During the observations made in following up the feeding animals

Table 8

Percentage formed by trees and shrubs in European bison's food obtained by browsing and barking.

\begin{tabular}{lcc}
\hline \multicolumn{1}{c}{ Species } & Barking & Browsing \\
\hline 1. Quercus robur & 46.5 & 6.1 \\
2. Carpinus betulus & 21.6 & 18.7 \\
3. Fraxinus excelsior & 17.0 & 12.3 \\
4. Ulmus laevis & 4.2 & 6.2 \\
5. Salix caprea & 3.2 & 13.4 \\
6. Tilia cordata & 3.2 & 8.8 \\
7. Picea excelsa & 2.0 & 0.04 \\
8. Alnus glutinosa & 1.9 & 0.1 \\
9. Acer platanoides & 0.2 & 0.6 \\
10. Corylus avellana & 0.2 & 2.1 \\
Other & - & 31.6 \\
\hline
\end{tabular}

a further 8 species of grasses, sedges and rushes were recorded as being included in the European bison's food (Table 6).

The final group includes 84 species of dicotyledonous forbs, and a total of 27,219 contacts were recorded for this group during the whole of the study period. The highest percentage of contacts was recorded for Aegopodium podagraria - $18.2 \%$, Urtica dioica - $13.4 \%$, Ranunculus lanuginosus - 9.3\%, and Cirsium oleraceum - 6.5\% (Table 6).

\section{Species Preferences and Abundance Coefficient}

The list of plants included in the European bison's food was compared with a list of plants occuring in the study areas. For this purpose calculation was made of frequency of occurrence (on how many areas) of different plant species, phytosociological records being used as a basis 
for calculations. Then calculation was made according to the Braun-Blanquet scale of the percentage of different species for each area and on this basis the abundance coefficient $D$ (Deckungswert) was calculated, using the Braun-Blanquet equation ( $\mathrm{P}$ a w $ł$ ow ski, 1959):

$$
\mathrm{D}=\frac{\text { Total of average percentages of cover in all records } \times 100}{\text { Number of surveys }}
$$

Lists of different groups of plants were compared, according to the type of forest, and also for all types of forest jointly (cf. Table 6).

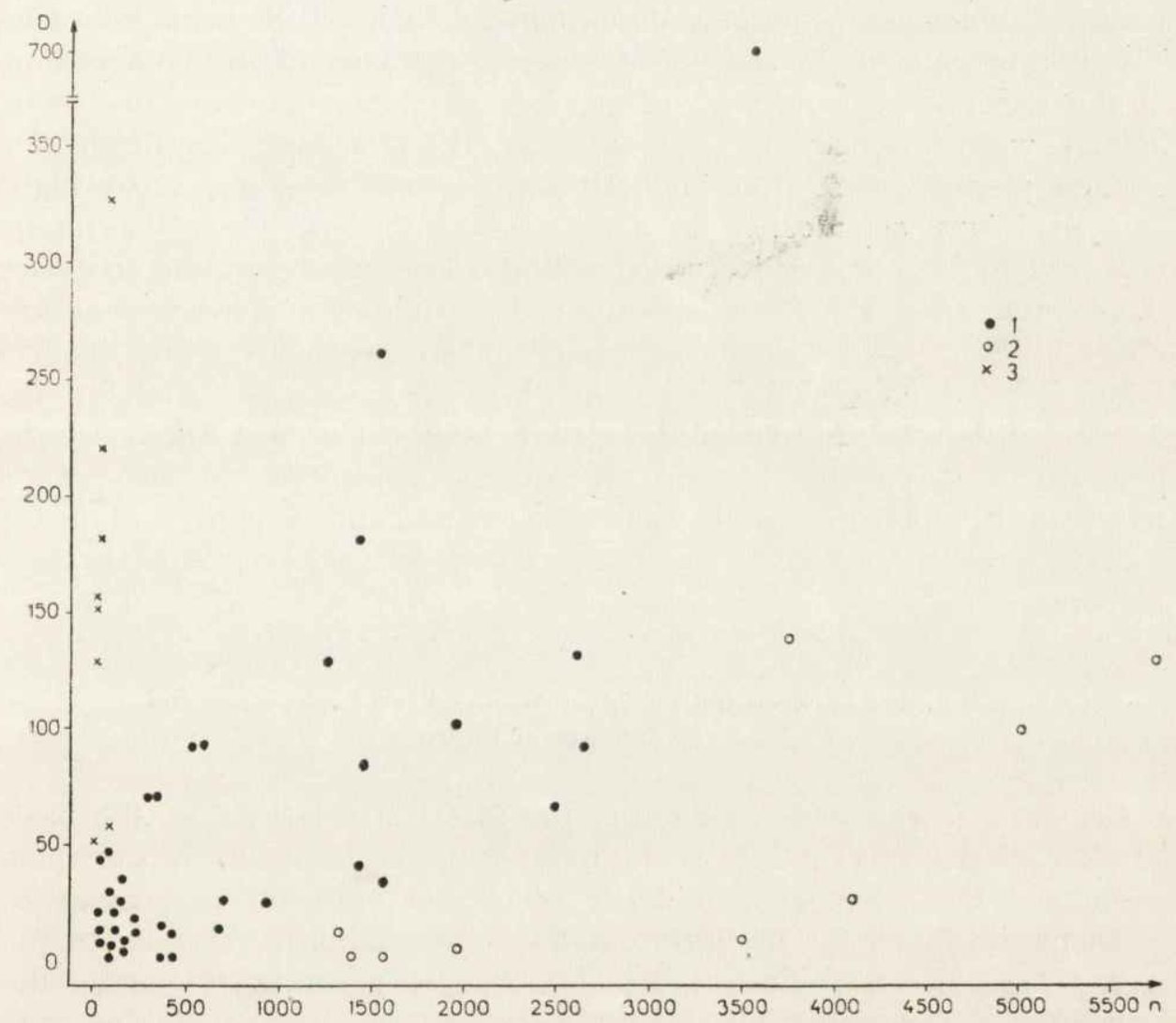

Fig. 1. Comparison of number of contacts (n) and abundance coefficient $(D)$.

1 - Number of contacts depends on abundance of plant, 2 - Plants readily eaten, but scanty in the area, 3 - Plants not readily eaten, but occurring abundantly in the area.

Comparison made in this way enabled several groups of plants to be distinguished (Fig. 1): 
1. Plants eaten in proportion to their numbers - a group in which the number of contacts rises with increase in abundance coefficient in different biotopes. Among these are, e.g. Carpinus betulus, Fraxinus excelsior, Tilia cordata, Ranunculus repens, Urtica dioica.

2. Preferred plants - a group of plants with low abundance coefficient, but frequently eaten by European bison, e.g. Salix caprea, Betula pubescens, Ulmus laevis, Ficaria verna, Centaurea jacea, Stachys silvatica, Digitalis ambigua.

3. Plants not liked - plants occurring abundantly, but forming a negligible percentage of the European bison's food, such as, e.g. Oxalis acetosella, Anemone nemorosa, Majanthemum bifolium, Stellaria holostea.

4. Plants avoided. In addition to species included in the composition of the European bison's food 127 species of plants not eaten by these animals were recorded on the study areas. The abundance coefficient $(D)$ of these plants is most often low, although in some cases it is fairly high, e.g. Aspidium spinulosum in Circaeo-Alnetum $(D=115)$, Vaccinium myrtillus in Peucedano-Pinetum $(D=1795)$, Trientalis europaea in Pino-Quercetum $(D=185)$, Chrysosplenium alternifolium in Circaeo-Alnetum $(D=335)$. Some of the plants in this group are poisonous (Paris quadrifolia, Daphne mezereum). There are also many mosses and lichens. Certain species in this group may have been eaten to a slight extent by the animals and the fact not recorded on account of the very small numbers in which they occur, and also on account of joint feeding by European bison and deer not being taken into consideration in this elaboration.

\section{Relation between the European Bison's Food Preferences and Type and Age of Forest}

Comparison was made in some of the forest associations, on the basis of a list of species (Table 6) of the number of species eaten by European bison and their average abundance coefficient with the percentage of consumption found for the different forest associations (Table 9). In the case of grasses and sedges information has been limited to giving the percentage of consumption in different associations, not taking into consideration the number of species and their abundance, on account of the lack of exactitude in identifying plants in this group to species.

The above comparison showed that in the tree and shrub group the number of species and their average abundance of occurrence is similar in the various biotopes, but that the percentage of consumption differs in Pino-Quercetum - 2.5\%, but in Calamagrostio-Quercetum - 38.4\% of the whole of the food eaten. This phenomenon can be explained by the 
fact that in Peucedano-Pinetum and Pino-Quercetum it is the species forming a negligible part of the European bison's food, such as Picea excelsa, Pinus silvestris, Rubus saxatilis, which predominate, and this results in the occurrence of a high abundance coefficient and low percentage of consumption. In Calamagrostio-Quercetum and Tilio-Carpinetum, both high and low variants, there is a high percentage of consumption caused by abundant occurrence of species preferred by European bison. e.g. Carpinus betulus, Fraxinus excelsior and Rubus idaeus.

Table 9

Comparison of abundance of plants in different biotopes with percentage of food consumed by the European bison in these biotopes.

\begin{tabular}{|c|c|c|c|c|}
\hline Type of & forest ${ }^{1}$ & $\begin{array}{l}\text { Trees, shrubs } \\
\text { dwarf-shrubs }\end{array}$ & Grasses, sedges & Forbs \\
\hline \multirow{3}{*}{$P-P$} & $\underline{\mathrm{n}}$ & 15 & \multirow[b]{3}{*}{0.1} & 16 \\
\hline & $\overline{\mathrm{D}}$ & 154 & & 34 \\
\hline & $\%$ & 2.5 & & 1.0 \\
\hline \multirow{3}{*}{$P-Q$} & $\mathrm{n}$ & 18 & \multirow[b]{3}{*}{20.2} & 47 \\
\hline & $\overline{\mathrm{D}}$ & 102 & & 42 \\
\hline & $\%$ & 8.1 & & 2.8 \\
\hline \multirow{3}{*}{$C-Q$} & $\underline{\mathrm{n}}$ & 18 & \multirow[b]{3}{*}{52.6} & 52 \\
\hline & $\overline{\mathrm{D}}$ & 98 & & 58 \\
\hline & $\%$ & 38.4 & & 33.5 \\
\hline \multirow{3}{*}{$T-C_{1}$} & $\underline{\mathrm{n}}$ & 14 & \multirow[b]{3}{*}{7.6} & 50 \\
\hline & $\overline{\mathrm{D}}$ & 103 & & 77 \\
\hline & $\%$ & 31.6 & & 32.4 \\
\hline \multirow{3}{*}{$T-C_{9}$} & $\underline{\mathrm{n}}$ & 18 & \multirow[b]{3}{*}{$19 . \overline{5}$} & 47 \\
\hline & $\overline{\mathrm{D}}$ & 74 & & 108 \\
\hline & $\%$ & 18.4 & & 24.6 \\
\hline \multirow{3}{*}{$C-A$} & $\mathrm{n}$ & 16 & \multirow[b]{3}{*}{-} & 41 \\
\hline & $\overline{\mathrm{D}}$ & 79 & & 160 \\
\hline & $\%$ & 1.0 & & 5.7 \\
\hline
\end{tabular}

${ }_{1} P-P$ - Peucedano-Pinetum, $P-Q-$ Pino-Quercetum, C-Q Calamagrostio-Quercetum, T-C - Tilio-Carpinetum, high Mazurian variant, $T-C_{2}-$ Tilio-Carpinetum, low Mazurian variant, C-A. - Circaeo-Alnetum. $\mathrm{n}$ - Number of species, $\bar{D}$ - Average abundance coefficient, $\%$ - Per cent of consumption.

In the group of grasses and sedges $79.7 \%$ of consumption occurs in $C-Q, T-C_{1}$ and $T-C_{2}$.

In the group of herb plants percentage of consumption depends on the number and abundance of species. For instance in $P$-P the percentage formed by dicotyledonous forbs in the European bison's food, in compa- 
rison with the other 5 biotopes is $1 \%$, with 16 species recorded as having an average abundance coefficient of 34 , whereas in $C-Q$ the figure was $33.5 \%$ of the whole of herb mass eaten, with 52 species occuring with an average abundance coefficient of 58 . Generally speaking it can be said that European bison consume least food in $P-P$ and $P-Q$, and most in $C-Q, T-C_{1}$ and $T-C_{2}$.

The low percentage of all contacts with plants occuring in Circaeo-Alnetum is surprising (trees and shrubs $1 \%$, grasses and sedges $0 \%$, herb plants $5.7^{0} \%$ ), since there is a large number of species there and

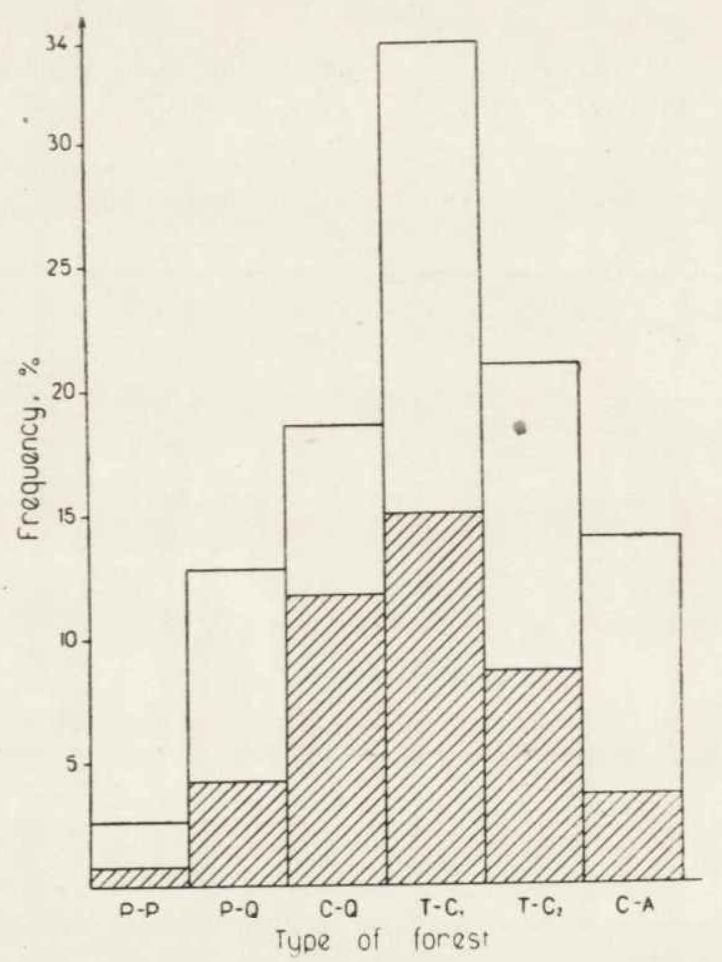

Fig. 2. Wanderings of European bison on all areas jointly, taking into consideration type of forest.

Height of columns indicates frequency of visits by these animals and shaded part - visits combined with feeding. $P-P-$ Peucedano-Pinetum, $P-Q-$ Pineto-Quercetum, C-P - Carpino-Pinetum, $T-C_{1}, T-C_{2}-$ Tilio-Carpinetum, C-A - Circaeo-Alnetum.

their average abundance coefficient is high. As only 24 cases of European bison feeding in $C$ - $A$ throughout the whole study period (maximum in $T-C_{1}$ forest - 97) it is reasonable to suppose that these animals do not readily wander over the marshy ground of $C$ - $A$ association despite the rich supply of food there. 
Figure 2 presents the European bison's wanderings over the control areas in the various biotopes. Their preference for $T-C_{1}$, where $34^{\%} \%$ of all the animals' visits took place, is particularly clearly evident. The frequency of the animals' feeding is distributed more or less analogically to the distribution of their visits to different types of forest and varies within limits from $31.2 \%$ in $P-P$ to $44.3 \%$ in $T-C_{1}$, and exceptionally $63.4^{\%} \%$ in $C-Q$. Frequency of feeding in $C-Q$ is highly different statistically $(P<0.005)$ than in the other types of forest, in which differences are rot statistically significant when checked with the chi-square test.

Distribution of visits by European bison in the three basic age categories of the tree stands - (1) young plantations and thickets, (2) pole-sized stand and (3) timberstand, is even. In the plantations, however, $58 \%$ of the animals' visits were combined with feeding, whereas in the two older groups of tree-stands this figure was slightly over $30 \%$ (Fig. 3).

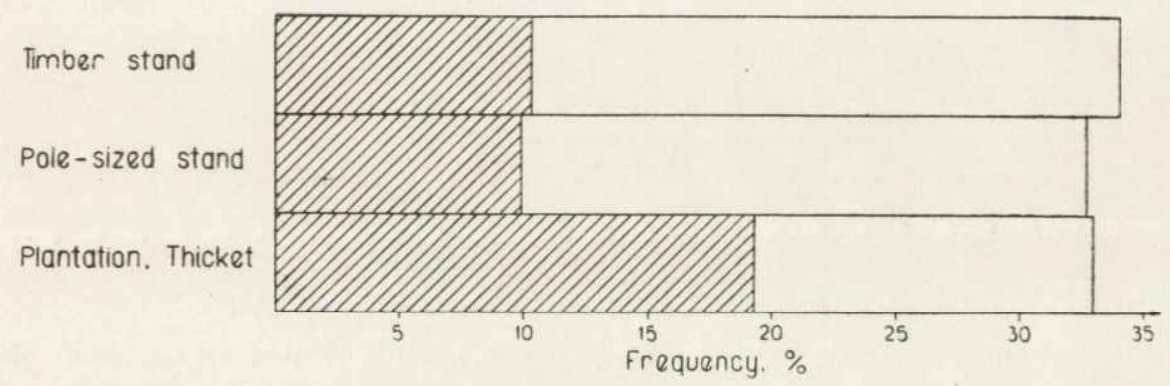

Fig. 3. Wanderings of European bison on all areas jointly, taking into consideration different age classes of the forest.

Length of columns indicates frequency of visits by European bison, and shaded part - visit combined with feeding.

In general it can be said that European bison in the Białowieża Primeval Forest most frequently feed on plantations and in biotopes $C-Q$, $T-C_{1}$ and $T-C_{2}$.

\section{Percentages of Different Kinds of Plants in the European Bison's Food}

Calculation was made of the percentages formed by different groups of plants in the European bison's food (Fig. 4), from which it can be seen that grasses and sedges, and also herbs, form $67 \%$ of the whole of these animals' food, and trees and shrubs, by browsing and barking $33 \%$, the bulk of the latter kind of food consisting of stripped bark $-26.6 \%$.

If we deduct from the whole of the animals' food the part composed of shrubs and trees which are not of economic importance in forest 
management it can be seen that species of economic importance such as, e.g. Fraxinus excelsior, Quercus robur, Acer platanoides, Alnus glutinosa, Pinus silvestris and Picea excelsa form $19.2 \%$ of the European bison's food, and $18 \%$ of it is obtained by barking and $1.2 \%$ by browsing. On this basis, and also the basis of the European bison's daily food requirements (Gębczyńska \& Krasińska, 1972), it is possible

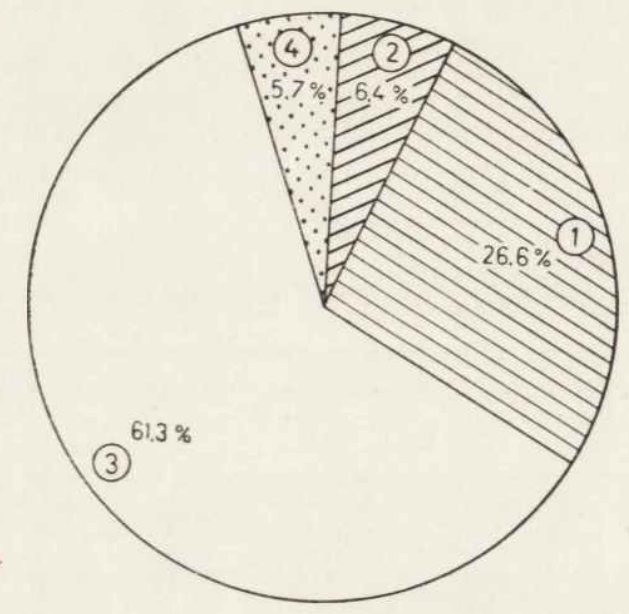

Fig. 4. Percentage formed by different groups of plants in food of European bison. 1 - Trees, shrubs - barking, 2 - Trees, shrubs - browsing, 3 - Grasses, sedges, 4 - Dicotyledonous forbs (herbs).

to define the degree of harm done by these animals during the period free of snow cover.

\section{DISCUSSION}

Data obtained from field observations in the Białowieża Primeval Forest in general coincide with results obtained in other reports. K or očkina (1969a, b) gives a list of 376 species of plants forming the European bison's food in the Soviet part of the Forest. As the study areas we marked out were small $(10 \times 50 \mathrm{~m})$ the rarer species of plants did not occur on them, and this is one of the reasons why our list contains only 112 species, and together with species recorded outside the areas, 137. The chief aim of our work was, however, to examine the European bison's food preferences depending on the habitat, and not to draw up a list of all plant species included in the food of this animal. 
In the group of trees and shrubs ( $\mathrm{K}$ o r o č k i n a, 1969a) gives 45 species. The order in which they are arranged is very similar, in respect of both number of contacts and abundance in the area to the results we obtained. The first places, with slight shifts in the order of precedence in comparison with our list, are occupied by oak, hornbeam, sallow, aspen, ash and pine.

In the group of grasses and sedges and dicotyledonous forbs $\mathrm{K}$ or očkina (1969b) gives 331 species, which she divides into 4 groups: (1) basic fodder - very frequently eaten, (2) supplementary - less readily eaten, (3) subordinate - rarely eaten, (4) random. This author does not, however, give the criteria used for allocating plants to the different groups, nor their abundance in the area, limiting her definitions to "plants very often, often, sometimes and rarely encountered " hence exact comparisons are impossible. Of the 10 species of dicotyledonous forbs occupying the first places on our list, only two - Aegopodium podagraria and Ranunculus lanuginosus, are defined by Koročkina as included in composition of the European bison's basic food. The remaining species she allocates either to "supplementary" or "subordinate "fodder. Part of the species allocated by Kor očkina $(1969 \mathrm{a}$, b) to "basic" food are included in our list, but they are species which did not occur on our study areas, and other species occurred in small numbers, but no cases of their being eaten by European bison were recorded.

S c i b or (1961) gives sallow, aspen, maple, ash and others from plants preferred by European bison, and claims that birch is not included in these animals' food. Our studies showed that European bison eat shoots of two species of birch: Betula pubescens and Betula verrucosa, forming respectively $11.5 \%$ and $4.6 \%$ of the total number of all contacts with trees consumed by cropping. This percentage is too high to be able to consider such cases as sporadic. As the majority of contacts with Betula verrucosa take place in biotopes poor in species eaten by European bison $(P-P$ and $P-Q)$ it may be considered that the participation of birch in the European bison's food depends on the abundance of the occurrence of deciduous trees of greater attraction to these animals.

$\mathrm{K}$ a m enskaja (1956) considers the nettle (Urtica dioica) as among frequently cropped plants which are not of great importance as food. Čičikina \& Čičikin (1967), in describing the food of European bison introduced into Kirghiz state, that nettles were completely avoided by these animal when feeding. Our studies showed that nettles form $13.4 \%$ of all the European bison's contacts with dicotyledonous plants and that they occupy the second place on the list. In the light of the foregoing Urtica dioica cannot be considered as of no significance in the diet of the European bison in the Białowieża Primeval Forest. The high 
level of consumption of nettles is connected, inter alia, with the abundance of this plant in the area. As shown by phytosociological records, the nettle occurs on 40 study areas. The abundance coefficient was jointly 707 for 6 biotopes (cf. Table 6). This phenomenon is undoubtedly connected with the hydrophilous character of nettles, which find very favourable living conditions in the marshy ground of the Polish part of the Białowieża Forest.

Gębczyńska \& Krasińska (1972) examined the European bison's food preferences under experimental conditions. The food preferences established by these authors in relation to different plant species coincide to a very great degree with the results of field observations. The differences found related to several species readily eaten by European bison under field conditions, but almost $100 \%$ of which were consumed under the conditions in the enclosure (Chaerophyllum hirsutum, Lysymachia vulgaris, Stellaria nemorum, Acer platanoides). As the number of species fed to the animals in the enclosure was far smaller than the number of species accessible to these animals under field conditions, the above phenomenon forms evidence of the plasticity of the European bison's food preferences.

The results obtained on the relation between abundance of food and the degree to which it is consumed by European bison, taking into consideration differences occurring in different types of forest and age classes of the tree stand directly affect the economic significance of the European bison in forest ecosystems. We have shown that European bison most readily feed in forests of the Calamagrostio-Quercetum, Tilio-Carpinetum, high and low variants, and particularly in plantations of young trees, and that bark stripping is of more importance than shoot cropping throughout the whole summer period.

These considerations should be borne in mind if it is intended to organize new European bison herds in other stretches of forest, and also in planning the further development of the herd in the Białowieża Primeval Forest, and in the cultivation operations carried out in this area.

No serious harm appears to be caused to forest management by European bison feeding on grasses, sedges and dicotyledonous forbs, or on trees and shrubs such as Carpinus betulus, Salix caprea and S. cinerea, Betula pubescens and B. verrucosa, Rubus idaeus, Tilia cordata and others. During the summer the European bison obtained $2 / 3$ of its food from grazing, and only $1 / 3$ from trees, only part of which are of considerable economic importance. These relations would be subject to significant change in winter if the supplementary feeding of these animals were to cease. Therefore in order fully to define the economic importance of the European bison in forest ecosystems it is essential 
to take winter feeding into consideration, which however can be done even for a herd left entirely to its own devices throughout all seasons of the year. It would also be necessary to take into consideration damage done, particularly in plantations and thickets, to the mere passage of herds of these powerful animals through them.

Our studies enabled us to define the natural food preferences of the European bison during the months of the year free of snow cover (April - November). As these animals congregate near feeding places in winter and only make use the natural food available to them in the forest to a small extent, a seasonal hiatus in observations was created, which of course affected final results to a certain extent, particularly those relating to the degree to which European bison consume parts of trees. It is to be expected that if supplementary food is not provided in winter the percentage of food from trees (chiefly bark stripped from them) would increase very considerably, as is shown by observations of several European bison which remained at a distance from the feeding places in winter. Six adult animals stripped $613,448 \mathrm{~cm}^{3}$ of bark (2,888 trees), chiefly ash, in an area of about 12 ha of forest within the period from December 1969 to the end of March 1970 (B or ow ski, in litt.).

In comparison with methods used by the authors of other studies on the food preferences of the European bison the study area method we used made it possible to define the percentage of different plant species in the food of these animals with greater accuracy. In addition location of the areas in different biotopes in the Białowieża Primeval Forest permitted of demonstrating the relation between consumption of food by the European bison and types of forest associations while a knowledge of abundance of different species in the areas made it possible to define the food preference of these animals.

Acknowledgements: The authors are greatly indebted to Professor Dr. Z. P ucek for his valuable advice and guidance during the collection and elaboration of material for this study. Their thanks are also due to technical assistants Mr. W. Bajko and Mr. A. Waszkiewicz for their assistance in collecting material under field conditions.

\section{REFERENCES}

1. Aleksandrov V. N. \& Golgofskaja K. Ju., 1965: Kormovye ugod'ja zubrov Kavkazskogo zapovednika. Tr. Kavkaz. gos. zapov., 8: 129-154.

2. Borowski S., Krasiński Z. \& Miłkowski L., 1967: Food and role of the European bison in forest ecosystems. Acta theriol., 12, 25: 367-376.

3. Čičikina S. N. \& Čičikin Ju. N., 1967: Akklimatizacija zubra v orehoplodovych lesah juga Kirgizii. [In: »Itogi akklimatizacii zverej v Kirgizii«, Ed. A. I. J a nus evi č] A. N. Kirgizsk. S. S. R., In-t Biologii., Izd. Ilim: 78-90, Frunze. 
4. Gębczyńska Z. \& Krasińska M., 1972: Food preferences and requirement of the European bison. Acta theriol., 17, 10: 105-117.

5. K a menskaja M. A., 1956: O kormah zubra v Prioksko-terrasnom zapovednike. Uč. Zap. Mosk. Gor. Ped. In-ta, Zool., 61, 4-5: 279-289.

6. K or o čk in a L. N., 1966: K voprosu o značenii drevesnoj rastitel'nosti v pitani zubrov Belovežškoj Pušči. Vesci A. N. B.S.S.R., 1: 106-111.

7. Kor očkin a L. N., 1969a: Drevesnaja rastitel'nost v pitani zubrov Belovežskoj Pušči. Belovežškaja Pušča, Issledovanija, 3: 120-126.

8. Koročkina L. N., 1969b: Vidovoj sostav lesnoj travianistoj rastitel'nosti v pitani zubrov Belovežskoj Pušči. Belovežskaja Pušča, Issledovanija, 3: 204221.

9. Koročkina L. N., 1971: Vlijanije zubrov na podrost drevesnoj rastitel'nosti Belovežskoj Pušči. Belovežskaja Pušča, Issledovanija, 4: 167-176.

10. Krajnova L. W., 1951: Pitanije zubrov Kavkazskogo gosudarstvennogo zapovednika. Bjull. Mosk. O-va Isp. Prirody, Biol., 56, 6: 3-17.

11. Krasiński Z., 1967: Free living European bisons. Acta theriol., 12, 28: 391405 .

12. M a tuszkiewicz W., 1967: Przegląd systematyczny zbiorowisk roślinnych Polski. [In: Scamoni A., „Wstęp do fitosocjologii praktycznej«]. Państw. Wyd. Roln. i Leśne: 175-234. Warszawa.

13. Pucek Z., 1967: The most important problems for further studies on European bison. Acta theriol., 12, 35: 495-501.

14. P a w low ski B., 1959: Skład i budowa zbiorowisk roślinnych oraz metodyka ich badań. [In: "Szata roślinna Polski« ed. W. Sz a f e r]. Państw. Wyd. Nauk.: 229-263, Warszawa.

15. Scibor J., 1961: Żubry w Puszczy Białowieskiej. Chr. Przyr. ojcz., 17, 3: 1626.

16. Z a b lo ckaja L. V., 1957: Pitanije i jestestvennye korma zubrov. Tr. Priokskoterrasn. gos. zapov., 1: 5-65.

Accepted, April 28, 1972.

Mammals Research Institute, Polish Academy of Sciences,

Białowieża.

Stanisław BOROWSKI i Simona KOSSAK

\section{NATURALNA PREFERENCJA POKARMOWA ŻUBRA W SEZONACH BEZ POKRYWY ŚNIEŻNEJ}

\section{Streszczenie}

Badania prowadzono na terenie polskiej części Puszczy Białowieskiej w latach 1966-71, metodą obserwacji żerująccyh zwierząt (1966-68), oraz kontroli 60 powierzchni badawczych o rozmiarach $10 \times 50 \mathrm{~m}$, rozmieszczonych w 6 typach lasu i trzech klasach wieku drzewostanu. Dla każdej powierzchni wykonano zdjęcia fitosocjologiczne i na tej podstawie obliczono współczynnik obfitości występowania po- 
szczególnych gatunków roślin na wszystkich powierzchniach łącznie. Żerowanie żubra na poszczególnych okazach roślin notowano w formie kontaktów, uznając za 1 kontakt zgryzienie 1 kępy trawy lub turzycy, zżarcie 1 pẹdu drzewa czy krzewu, $1 \mathrm{dcm}^{2}$ trawy lub turzycy wyżerowanej przy gruncie i zżarcie 1 okazu (całego lub fragmentu) rośliny zielnej. W celu ujednolicenia danych zebrano w terenie próby odpowiadające kontaktom z najczęściej jedzonymi przez żubry gatunkami drzew i krzewów, traw i turzyc oraz roślin zielonych, a następnie określono przeliczniki między nimi w oparciu o wartości suchej masy poszczególnych grup roślin. Ilość ospałowanej kory mierzono $\mathrm{w} \mathrm{cm}^{3}$.

Obserwacje dotyczą okresu bez pokrywy śnieżnej, gdyż zimą żubry gromadzą się przy paśnikach i nie penetrują powierzchni badawczych.

Całość danych uzyskanych na powierzchniach badawczych zebrano w listy gatunkowe zawierające drzewa i krzewy, trawy i turzyce oraz rośliny zielone pogrupowane wg procentowego udzialu poszczególnych gatunków w pokarmie żubra (Tabela 6$)$.

Łączny materiał wynosi 352.496 kontaktów i $21.488 \mathrm{~cm}^{3}$ ospałowanej kory. Ogólem stwierdzono w pokarmie żubra 112 gatunki roślin pobieranych na powierzchniach, a lącznie z gatunkami pobieranymi poza powierzchniami 137 .

W grupie drzew i krzewów na pierwszym miejscu znajduje się Carpinus betulus, Fraxinus excelsior, Salix caprea $i$ Rubus idaeus. Spałowaniu najczęściej ulega Quercus robur, Carpinus betulus i Fraxinus excelsior (Ryc. 1).

$\mathrm{Z}$ grupy traw i turzyc najczęściej jedzone byly Calamagrostis arundinacae, Carex silvatica i Carex hirta.

Największy procentowy udział w pokarmie żubra w grupie roślin zielonych mają Aegopodium podagraria, Urtica dioica i Ranunculus lanuginosus.

Porównano procentowy udzial poszczególnych gatunków w pożywieniu żubra z obfitością tych roślin $w$ terenie. W wyniku powyższego wyodrębniono 3 grupy roślin; licznych i chętnie jedzonych, licznych niechętnie jedzonych, nielicznych a chętnie jedzonych (Rycina 2). Zanotowano również 127 gatunków występujących na powierzchniach a nie wchodzących w skład żeru żubra. Kilka z nich występuje licznie.

Prześledzono zależność preferencji pokarmowej żubra od typu i wieku lasu. Preferowane są biotopy bogate w gatunki stanowiące pokarm żubra (Rycina 3). W biotopach ubogich pod tym względem notuje się wzrost spożycia niektórych gatunków omijanych w biotopach bogatych (Betula verrucosa). Żubry najchętniej żerują w młodnikach i uprawach (Ryc. 4).

Procentowy udział poszczególnych grup roślin w pokarmie żubra kształtuje się następująco: trawy i turzyce oraz rośliny zielne stanowią $67 \%$, drzewa i krzewy pobierane przez zgryzanie i spałowanie 33\% (Rycina 5). Pokarm drzewiasty mający istotne znaczenie gospodarcze wynosi $19,2 \%$ całości żeru żubra. 